\title{
FAMILY FARM INCOME AND THEIR PRODUCTION AND ECONOMIC DETERMINANTS ACCORDING TO THE ECONOMIC SIZE IN THE EU COUNTRIES IN 2004-2015
}

\author{
Roma Ryś-Jurek, $\mathrm{PhD}^{1}$ \\ Faculty of Economics and Social Sciences, Poznań University of Life Sciences
}

\begin{abstract}
The aim of this research is to present the family farm income and production and its economic determinants according to the economic size of farms in the EU countries in 2004-2015. Research is based on European Farm Accountancy Data Network (FADN), which includes information about average farms according to the economic size in the EU-28. In this article an attempt is made to use the panel models to evaluate the production and economic determinants of family farm income. The Gretl program is used to evaluate fixed effect models and random effect models. The production and economic determinants of family farm income depending on the farm's size are indicated, such as: utilised agricultural area, crop and livestock production, net investment and cash flow and inputs.
\end{abstract}

Key words: economic size of farm, family farm income, production

JEL codes: Q10, Q14

\section{INTRODUCTION}

The FAO defines a family farm as 'an agricultural holding, which is managed and operated by a household and where farm labour is largely supplied by that household'. Family farms are by far the most common type of farm in the European Union (EU). There is a wide range of agricultural holdings starting from small, semi-subsistence farms with only family workers and farms, which have to rely on other activities in order to diversify sources of income, ending with larger, more productive farms, which nevertheless pursue family management (Eurostat, 2016). The support of family income of these farms (by direct payments) remains an essential part of the
Common Agricultural Policy (CAP) in line with EU Treaty obligations (European Commission, 2017).

Taking into account abovementioned considerations, as well as the primary aim of CAP to support incomes in agriculture, the purpose of the paper is to examine the production and economic determinants of family farm income. According to the hypothesis of research, determinants affecting income vary depending on the economic size of the farm.

\section{THEORETICAL BACKGROUND}

Family farm net income results from the agriculture economic production during the operating year in which the agricultural goods are produced. It rep-

${ }^{1}$ Corresponding author: Wojska Polskiego 28,60-637 Poznań, Poland, rysjurek@up.poznan.pl, +4861 8487117 
resents the return to owner's equity, unpaid labour, management and risk (AAFC and Statistics Canada, 2000).

Growth in farmers' incomes is fundamental to economic and social development and to farmers' ability to reinvest in their farms (Sustainable Food Lab, 2017). The most commonly mentioned characteristics of family farms include the combination of home and business life. The tendency for a greater proportion of family living and farm production cost items to be raised on the farm makes the predominant role of the operator and his family in labour and management (Scoville, 1947).

According to the household socio-economic point of view, the aim of the household is to maximize income from crop and livestock activities under certain circumstances (Nibbering and van Rheenen, 1998). Farming is a risky business because forces beyond the control of farmers, such as weather, affect their income. Therefore, farm income stability has been one of the goals of agricultural policies both in the US and the EU (Severini et al., 2016) ${ }^{2}$, as well as the farms' income ${ }^{3}$. Making a satisfactory income and safeguarding it for the future are the mains goals of farmers (Gasson, 1973; Cary and Holmes, 1982; Berbel and Rodriguez-Ocaña, 1998; Solano et al., 2001).

It should be emphasized that there is a great divergence in the incomes of farmers obtained even in al- most identical farms. No size of farm is large enough to ensure a profit. Therefore, some level of management must be specified in an 'adequate income' concept. Proper size of family farms according to any income concept would vary with changes in prices and costs (Scoville, 1947).

The structure of the paper takes into account abovementioned considerations as well as the main research. Therefore, section 3 gives the methodological background of the research. Section 4 presents the results of the econometric analysis. Section 5 concludes.

\section{MATERIALS AND METHODS}

Research is based on the data obtained from Farm Accountancy Data Network (FADN), because only the professional farms (i.e. the farms which are large enough to provide a main activity for the farmer and a level of income sufficient to support his or her family) are included in FADN. The FADN has developed a detailed methodology for calculating the family farm income (Fig. 1). The FADN data enable a detailed presentation and analysis of the production and economic determinants of the family farm income (FADN 2018).

These data include basic information about economic situation of ca 1680 production types according to the economic size in the EU in the years 2004-2015 . FADN data has a character of the panel

\footnotetext{
${ }^{2}$ The long tradition of widespread support for farm income is unique in agriculture as compared to other sectors (Frawley et al., 2000). Income policy has a number of different purposes, namely: forming desired income relations, shaping the level of income, stabilising income over time, i.e. mitigating fluctuations in income from year to year and reducing income inequalities between different agricultural population groups. Changes in agricultural income are mainly due to fluctuations in agricultural production, which depend on natural (mainly weather factors) and economic factors. The effects of fluctuations in production on income may be offset by changes in prices and compensation under the production risk insurance (Pawłowska-Tyszko, 2014).

${ }^{3}$ Farmers are continuously making decisions concerning how they allocate their resources of land, labour, capital and entrepreneurial ability. Such behaviour is motivated by the desire to maximise levels of satisfaction or utility. Most studies that have modelled farmer decision-making have, however, assumed a single objective of profit maximisation as the motivation for decision-making behaviour. Therefore, a farmer may be interested in increasing gross margin, reducing indebtedness, avoiding risk, expanding the business, improving family living standard, achieving sufficient leisure time, etc., but not necessarily in that order (Wallace and Moss, 2002).

${ }^{4}$ The economic size of farms is one of the criteria used to classify agricultural holdings according to the Community typology for agricultural holdings. In line with Commission Regulation (EC) No 1242/2008, the economic size of an agricultural holding is measured as the total Standard Output (SO) of the holding expressed in euro. The Standard Output is the average monetary value of the agricultural output at farm-gate price of each agricultural product (crop or livestock) in a given
} 


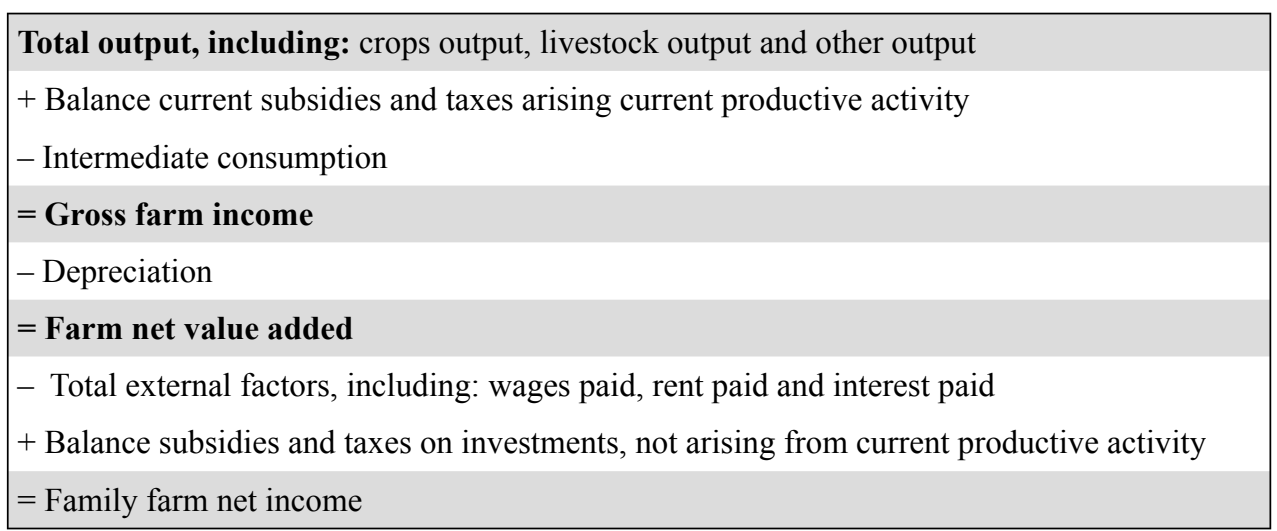

Figure 1. Calculation of the family farm net income according to the FADN methodology

Source: own work based on FADN 2018.

data $^{5}$. A particular production type according to the economic size is an aggregate unit. This average volume is calculated on the basis of many individual farms with the same production direction and economic size in each country in the EU. A whole database consists of 28 countries $^{6}$.

Next, the most general formulation of a panel data model may be expressed by the following equation (Baltagi, 2005):

$$
y_{i, t}=\alpha_{\mathrm{i}}+X^{\prime}{ }_{i, t} \beta+u_{i, t}+\varepsilon_{i, t}
$$

with $i(i=1, \ldots, N)$ denoting individuals, $t(t=1, \ldots, T)$ denoting time periods, and $X^{\prime}{ }_{i, t}$ denoting the observation of $K$ explanatory variables in country $i$ and time $t$. It should be noted that $\alpha_{i}$ is time invariant and accounts for any individual-specific effect not included in the regression equation. Two different interpretations may be given to the $\alpha_{i}$, and, consequently, two different basic models may be distinguished. If the $\alpha_{i}$ 's are assumed to be fixed parameters to be estimated the model expressed in the equation (1) is termed Fixed Effect Panel Data Model (FEM). Conversely, if the $\alpha_{i}$ 's are assumed to be random, the Random Effect Panel Data Model (REM) is generated (Arbia and Piras, 2005) ${ }^{7}$.

In order to choose between Random and Fixed Effect Model, the Hausman test is used ${ }^{8}$. The null and alternative hypotheses of Hausman test are (Adkins, 2014):

$$
H_{\mathrm{o}}: \operatorname{Cov}\left(x_{i} ; e_{i}\right)=0 \text {, against } H_{a}: \operatorname{Cov}\left(x_{i} ; e_{i}\right) \neq 0 \text {. }
$$

region. According to the Farm Accountancy Data Network, the Standard Output is calculated by Member States per hectare or per head of livestock, by using basic data for a reference period of 5 successive years. Among 6 classes of economic size, some further subclasses of farms can be distinguished: from EUR 2,000 to 8,000 - very small farms, from EUR 8,000 to 25,000 - small farms, from EUR 25,000 to 50,000 - medium-low farms, from EUR 50,000 to 100,000 - medium-large farms, from EUR 100,000 to 500,000 - large farms, and above EUR 500,000 - very large farms.

${ }^{5}$ A panel data (or longitudinal data) set consists of a time series for each cross-sectional member in the data set over a time period. Panel data can also be collected on geographical units (Wooldridge, 2013). Panel data models allow us to construct and test more complicated behavioural models than purely cross-section or time-series data (Baltagi, 2005).

${ }^{6}$ The Farm Accountancy Data Network website http://ec.europa.eu/agriculture/rica [Accessed 05.05.2018].

${ }^{7}$ Fixed Effect Model is particularly indicated when the regression analysis is limited to a precise set of individuals, firms or regions; random effect, instead, is an appropriate specification if we are drawing a certain number of individuals randomly from a large population of reference (Arbia and Piras, 2005).

${ }^{8}$ The idea is that one uses the random effects estimates unless the Hausman test rejects. In practice, a failure to reject means either that the RE and FE estimates are sufficiently close so that it does not matter which one is used, or the sampling variation is so large in the FE estimates that one cannot conclude practically significant differences are statistically significant (Wooldridge, 2013). 
Proceedings of the 2018 International Scientific Conference 'Economic Sciences for Agribusiness and Rural Economy' No 2, Warsaw, 7-8 June 2018, pp. 21-28

Also, the Variance Inflation Factors (VIF) is used to measure how much the variance of the estimated coefficients is increased over the case of no correlation among the independent variables. If $\mathrm{VIF}=0$ there is no multicollinearity, but if $\mathrm{VIF} \geq 0$ there is multicollinearity (Ergün and Göksu, 2013). If the value of VIF test of variable exceeds 10.0, then there is evidence of a collinearity problem (Adkins, 2014).

\section{RESULTS AND DISCUSSION}

The first stage of empirical research is to present a family farm net income and chosen economic characteristics according to the economic size of farms in 2004 and 2015 (Table 1). In 2015, the average family farm net income in the EU-28 was equal to EUR 17.5 thousands from 34 ha, EUR 72.0 thousands of output and about EUR 339 thousands of assets. In the same time, the average liabilities of farm was equal to
EUR 54.5 thousands and total obtained subsidies to about EUR 11.7 thousands. As compared to 2004, the output and assets increased about $20 \%$ and liabilities about $30 \%$. The subsidies have increased only by $5 \%$. Meanwhile, income, area and the labour input has slightly decreased. The larger the economic size of the farm was, the higher value was derived by income and other variables. For example, in 2015 the smallest farms achieved only EUR 2 thousands of income, EUR 6 thousands of output and about EUR 40 thousands of assets at the area of 4.5 ha. While the largest farms reached about EUR 150 thousands of income, EUR 1.1 million of output and almost 1 million EUR of assets at the area of the 292 ha (Table 1).

The main target of research is to obtain the model that characterizes production and economic determinants of the family farm income according to the economic size of farm. In order to specify the model, a set of variables presented in Table 2 is used. Using

Table 1. Family farm net income and chosen economic characteristics according to the economic size of farms in 2004 and 2015

\begin{tabular}{|l|c|c|c|c|c|c|c|c|}
\hline \multirow{2}{*}{ Details } & UAA & $\begin{array}{c}\text { Family farm } \\
\text { net income }\end{array}$ & Output & Assets & $\begin{array}{c}\text { Labour } \\
\text { input }\end{array}$ & Liabilities & $\begin{array}{c}\text { All } \\
\text { subsidies }\end{array}$ \\
\cline { 2 - 10 } & ha & \multicolumn{3}{|c|}{ EUR thous. } & AWU & \multicolumn{2}{|c|}{ EUR thous. } \\
\hline 2004 EU-25, in detail (EUR): & $\mathbf{3 5 . 0 8}$ & $\mathbf{1 7 . 9 4}$ & $\mathbf{6 0 . 6 3}$ & $\mathbf{2 7 6 . 8 5}$ & $\mathbf{1 . 6 6}$ & $\mathbf{4 1 . 5 9}$ & $\mathbf{1 1 . 0 0}$ \\
\hline (1) $2000-<8000$ & 7.83 & 4.60 & 8.88 & 68.85 & 1.11 & 0.68 & 2.18 \\
\hline (2) $8000-<25000$ & 15.43 & 9.07 & 18.15 & 128.88 & 1.34 & 4.52 & 4.55 \\
\hline (3) $25000-<50000$ & 34.06 & 17.32 & 41.68 & 259.45 & 1.54 & 20.35 & 10.60 \\
\hline (4) $50000-<100000$ & 57.51 & 25.89 & 74.33 & 393.42 & 1.74 & 50.09 & 18.59 \\
\hline (5) $100000-<500000$ & 94.46 & 49.80 & 196.00 & 789.99 & 2.61 & 170.03 & 31.47 \\
\hline (6) $\geq 500000$ & 290.1 & 125.97 & 887.82 & 2192.65 & 11.58 & 668.46 & 82.98 \\
\hline 2015 EU-28, in detail (EUR): & $\mathbf{3 4 . 0 5}$ & $\mathbf{1 7 . 4 8}$ & $\mathbf{7 2 . 1 0}$ & $\mathbf{3 3 8 . 6 1}$ & $\mathbf{1 . 5 3}$ & $\mathbf{5 4 . 5 4}$ & $\mathbf{1 1 . 6 5}$ \\
\hline (1) $2000-<8000$ & 4.56 & 2.04 & 5.97 & 40.29 & 1.02 & 0.30 & 1.07 \\
\hline (2) $8000-<25000$ & 14.51 & 8.52 & 19.14 & 160.95 & 1.19 & 4.18 & 5.26 \\
\hline (3) $25000-<50000$ & 30.34 & 15.63 & 41.93 & 319.99 & 1.43 & 19.15 & 11.23 \\
\hline (4) $50000-<100000$ & 54.98 & 26.56 & 82.09 & 502.33 & 1.69 & 50.92 & 18.71 \\
\hline (5) $100000<<500000$ & 104.84 & 53.37 & 234.31 & 997.36 & 2.49 & 199.20 & 35.38 \\
\hline (6) $\geq 500000$ & 292.24 & 150.58 & 1107.77 & 3157.14 & 8.99 & 1066.46 & 101.98 \\
\hline
\end{tabular}

AWU - annual work unit, full-time person equivalent.

Source: own work based on FADN database. 
Table 2. The characteristic of potential variables used in panel models

\begin{tabular}{|c|c|c|}
\hline Symbol & Variable name & Variable characteristic \\
\hline$Y$ & Family farm income & $\begin{array}{l}\text { Remuneration to fixed factors of production of the farm (work, land and } \\
\text { capital) and remuneration to the entrepreneurs risks (loss/profit) in the } \\
\text { accounting year (EUR thous.). }\end{array}$ \\
\hline$X 01$ & Total utilised agricultural area & $\begin{array}{l}\text { It consists of land in owner occupation, rented land and land in share- } \\
\text { cropping (remuneration linked to output from land made available). It in- } \\
\text { cludes agricultural land temporarily not under cultivation for agricultural } \\
\text { reasons or being withdrawn from production as part of agricultural policy } \\
\text { measures. Does not include areas used for mushrooms, land rented for } \\
\text { less than one year on an occasional basis, woodland and other farm areas, } \\
\text { e.g. roads, ponds, non-farmed areas (ha). }\end{array}$ \\
\hline$X 02$ & Total labour input & Is expressed in annual work unit - full-time person equivalent (AWU). \\
\hline$X 03$ & Unpaid labour input & $\begin{array}{l}\text { Refers generally to family labour and is expressed in the family work unit } \\
\text { - family AWU (FWU). }\end{array}$ \\
\hline$X 04$ & $\begin{array}{l}\text { Total output crops and crop } \\
\text { production }\end{array}$ & $\begin{array}{l}\text { Is equal to: sales }+ \text { farm use }+ \text { farmhouse consumption }+ \text { (closing valua- } \\
\text { tion }- \text { opening valuation) (EUR thous.). }\end{array}$ \\
\hline$X 05$ & $\begin{array}{l}\text { Total output livestock and live- } \\
\text { stock products }\end{array}$ & $\begin{array}{l}\text { Is equal to: livestock production }+ \text { change in livestock value }+ \text { animal } \\
\text { products (EUR thous.). }\end{array}$ \\
\hline$X 06$ & Taxes & $\begin{array}{l}\text { Farm taxes and other dues (not including VAT and the personal taxes of } \\
\text { the holder) and taxes and other charges on land and buildings (EUR tho- } \\
\text { us.). }\end{array}$ \\
\hline$X 07$ & Total inputs & $\begin{array}{l}\text { Is equal to: specific costs }+ \text { overheads }+ \text { depreciation }+ \text { external factors. } \\
\text { Costs linked to the agricultural activity of the holder and related to the } \\
\text { output of the accounting year without the personal taxes of the holder } \\
\text { (EUR thous.). }\end{array}$ \\
\hline$X 08$ & $\begin{array}{l}\text { Balance current subsidies and } \\
\text { taxes }\end{array}$ & $\begin{array}{l}\text { Is equal to: farm subsidies + VAT balance on current operations - farm } \\
\text { taxes (EUR thous.). }\end{array}$ \\
\hline$X 09$ & $\begin{array}{l}\text { Balance subsidies and taxes on } \\
\text { investments }\end{array}$ & $\begin{array}{l}\text { Is equal to: subsidies on investments }+ \text { premiums for the cessation of } \\
\text { dairy farming - VAT paid on investments (EUR thous.). }\end{array}$ \\
\hline$X 10$ & Total fixed assets & $\begin{array}{l}\text { Agricultural land and farm buildings and forest capital }+ \text { buildings }+ \text { ma- } \\
\text { chinery and equipment }+ \text { breeding livestock (EUR thous.). }\end{array}$ \\
\hline$X 11$ & Total current assets & $\begin{array}{l}\text { Non-breeding livestock }+ \text { circulating capital (stocks of agricultural pro- } \\
\text { ducts }+ \text { other circulating capital) (EUR thous.). }\end{array}$ \\
\hline$X 12$ & Total liabilities & $\begin{array}{l}\text { Value at closing valuation of total of (long-, medium- or short-term) loans } \\
\text { still to be repaid (EUR thous.). }\end{array}$ \\
\hline$X 13$ & Equity & Total assets without the liabilities (EUR thous.). \\
\hline$X 14$ & Gross investment & $\begin{array}{l}\text { Is equal to: purchases - sales of fixed assets + breeding livestock change } \\
\text { of valuation (EUR thous.). }\end{array}$ \\
\hline$X 15$ & Net investment & Gross investment without the depreciation (EUR thous.). \\
\hline$X 16$ & Cash flow & $\begin{array}{l}\text { Is equal to: receipts - expenditure for the accounting year, not taking into } \\
\text { account operations on capital and on debts and loans (EUR thous.). }\end{array}$ \\
\hline
\end{tabular}

Source: own work based on FADN 2018. 
Proceedings of the 2018 International Scientific Conference 'Economic Sciences for Agribusiness and Rural Economy' No 2, Warsaw, 7-8 June 2018, pp. 21-28

the Gretl program, forward stepwise variable selection is introduced. As a result, the RE and FE Models are obtained. Results of the estimation of its parameters are presented in Table 3.

In the obtained models, all variables are characterized by level of significance about 0.05 . Five variables have positive and statistically significant influence on dependent variable, namely: agricultural area, crop and livestock output, net invest- ment and cash flow. This means that the higher the values of these variables, the higher the value of family farm net income. The highest positive influence on a dependent variable is exerted by cash flow. Family farm net income is also negatively impacted by variable inputs. Overall correctness of classification is high (between 67.29 and 96.12\%). The values of VIF test for all variables are below 10.0 (Table 3).

Table 3. Panel models for family farm income according to the economic size of farm

\begin{tabular}{|c|c|c|c|c|c|c|c|}
\hline \multirow{2}{*}{\multicolumn{2}{|c|}{ Details }} & \multicolumn{6}{|c|}{ Class of economic size } \\
\hline & & 1 & 2 & 3 & 4 & 5 & 6 \\
\hline \multicolumn{2}{|c|}{ Hausman test } & $\begin{array}{l}\chi 2(6)= \\
9.1655 \\
(0.1645)\end{array}$ & $\begin{array}{l}\chi 2(5)= \\
8.4854 \\
(0.1314)\end{array}$ & $\begin{array}{l}\chi 2(5)= \\
10.3524 \\
(0.0658)\end{array}$ & $\begin{array}{l}\chi 2(6)= \\
12.0654 \\
(0.0605)\end{array}$ & $\begin{array}{l}\chi 2(6)= \\
16.8168 \\
(0.0010)\end{array}$ & $\begin{array}{l}\chi 2(5)= \\
12.6614 \\
(0.0778)\end{array}$ \\
\hline \multicolumn{2}{|c|}{ Model's type } & REM & REM & REM & REM & FEM & REM \\
\hline $\begin{array}{l}(\mathrm{FEM}) \\
\text { LSDV R }^{2}\end{array}$ & $\begin{array}{l}\text { (REM) } \\
\text { theta }\end{array}$ & 0.7126 & 0.7408 & 0.7871 & 0.7514 & 0.9612 & 0.6729 \\
\hline $\begin{array}{l}(\mathrm{FEM}) \\
\text { within } \mathrm{R}^{2}\end{array}$ & $\begin{array}{c}(\text { REM }) \\
\text { corr(y.yhat })^{2}\end{array}$ & 0.9476 & 0.8938 & 0.8710 & 0.8960 & 0.9009 & 0.9334 \\
\hline \multicolumn{8}{|c|}{ Variables in model } \\
\hline \multicolumn{2}{|l|}{ const } & $\begin{array}{c}-0.105781 \\
(0.6694)\end{array}$ & $\begin{array}{c}-0.897052 \\
(0.0718)^{*}\end{array}$ & $\begin{array}{c}-5.003070 \\
(0.0000)^{* * *}\end{array}$ & $\begin{array}{c}-1.750070 \\
(0.1886)\end{array}$ & $\begin{array}{l}-6.660050 \\
(0.0263)^{* *}\end{array}$ & $\begin{array}{l}-107.77000 \\
(0.0000)^{* * *}\end{array}$ \\
\hline \multicolumn{2}{|c|}{$\begin{array}{l}\text { X01 - Total utilised } \\
\text { agricultural area }\end{array}$} & $\begin{array}{c}0.056522 \\
(0.0001)^{* * *} \\
{[1.934]} \\
\end{array}$ & & $\begin{array}{c}0.047421 \\
(0.0003)^{* * *} \\
{[1.076]}\end{array}$ & $\begin{array}{c}0.020078 \\
(0.0363)^{* *} \\
{[1.655]}\end{array}$ & $\begin{array}{c}0.037118 \\
(0.0000)^{* * *} \\
{[4.1919]} \\
\end{array}$ & \\
\hline \multicolumn{2}{|c|}{$\begin{array}{l}X 04 \text { - Total output crops } \\
\text { and crop production }\end{array}$} & $\begin{array}{c}0.394979 \\
(0.0000)^{* * *} \\
{[4.461]}\end{array}$ & $\begin{array}{c}0.214592 \\
(0.0000)^{* * *} \\
{[1.290]}\end{array}$ & $\begin{array}{c}0.235930 \\
(0.0000)^{* * *} \\
{[1.228]}\end{array}$ & $\begin{array}{c}0.273229 \\
(0.0000)^{* * *} \\
{[2.018]}\end{array}$ & $\begin{array}{c}0.409354 \\
(0.0000)^{* * *} \\
{[5.609]}\end{array}$ & $\begin{array}{c}0.249140 \\
(0.0000)^{* * *} \\
{[4.662]}\end{array}$ \\
\hline \multicolumn{2}{|c|}{$\begin{array}{l}X 05 \text { - Total output } \\
\text { livestock and livestock } \\
\text { products }\end{array}$} & $\begin{array}{c}0.653605 \\
(0.0000)^{* * *} \\
{[2.245]}\end{array}$ & $\begin{array}{c}0.143545 \\
(0.0000)^{* * *} \\
{[2.568]}\end{array}$ & $\begin{array}{c}0.239659 \\
(0.0000)^{* * *} \\
{[1.871]}\end{array}$ & $\begin{array}{c}0.229103 \\
(0.0000)^{* * *} \\
{[2.281]}\end{array}$ & $\begin{array}{c}0.359042 \\
(0.0000)^{* * *} \\
{[3.944]}\end{array}$ & $\begin{array}{c}0.292166 \\
(0.0000)^{* * *} \\
{[5.515]}\end{array}$ \\
\hline \multicolumn{2}{|c|}{$X 07$ - Total inputs } & $\begin{array}{c}-0.498078 \\
(0.0000)^{* * *} \\
{[1.522]}\end{array}$ & $\begin{array}{c}-0.198257 \\
(0.0000)^{* * *} \\
{[2.736]}\end{array}$ & $\begin{array}{c}-0.228355 \\
(0.0000)^{* * *} \\
{[1.737]}\end{array}$ & $\begin{array}{c}-0.292394 \\
(0.0000)^{* * *} \\
{[2.062]}\end{array}$ & $\begin{array}{c}-0.375233 \\
(0.0000)^{* * *} \\
{[5.116]}\end{array}$ & $\begin{array}{c}-0.260336 \\
(0.0000)^{* * * *} \\
{[9.326]}\end{array}$ \\
\hline \multicolumn{2}{|c|}{$X 15$ - Net investment } & $\begin{array}{c}0.086705 \\
(0.0000)^{* * *} \\
{[1.171]}\end{array}$ & $\begin{array}{c}0.162161 \\
(0.0000)^{* * *} \\
{[1.284]}\end{array}$ & & $\begin{array}{c}0.109576 \\
(0.0000)^{* * *} \\
{[1.370]}\end{array}$ & $\begin{array}{c}0.143888 \\
(0.0000)^{* * *} \\
{[1.521]}\end{array}$ & $\begin{array}{c}0.143658 \\
(0.0005)^{* * *} \\
{[1.708]}\end{array}$ \\
\hline \multicolumn{2}{|c|}{$X 16$ - Cash flow } & $\begin{array}{c}0.677099 \\
(0.0000)^{* * *} \\
{[2.919]}\end{array}$ & $\begin{array}{c}0.849730 \\
(0.0000)^{* * *} \\
{[1.296]}\end{array}$ & $\begin{array}{c}0.822875 \\
(0.0000)^{* * *} \\
{[1.194]}\end{array}$ & $\begin{array}{c}0.789176 \\
(0.0000)^{* * *} \\
{[1.418]}\end{array}$ & $\begin{array}{c}0.651911 \\
(0.0000)^{* * *} \\
{[1.710]}\end{array}$ & $\begin{array}{c}1.011470 \\
(0.0000)^{* * * *} \\
{[1.294]}\end{array}$ \\
\hline
\end{tabular}

The levels of significance in round brackets. The value of VIF test in square brackets.

Source: own calculations. 
The influence of independent variables on a family farm income is the strongest among the smallest farms. In this class of farms, the highest impact on the family income is exerted by the type of production and the amount of costs, and the lowest - by net investments. However, in the group of very large farms, the importance of the type of production is lower than the cash flow, and the area is irrelevant (Table 3). Therefore, obtained results allow to reject the hypothesis of research, according to which determinants affecting income were vary depending on the economic size of the farm.

\section{CONCLUSIONS}

Family farm income is a remuneration to work, land and capital of the farm and remuneration to the entrepreneurs' risks. The larger the economic size of the farm, the higher are the values of farms' income and area, output, assets, liabilities, etc.

On the basis of panel models, the article presents the family farm incomes and their economic and production determinants, such as: agricultural area, crop and livestock output, inputs, net investment and cash flow. The preliminary hypothesis of research, that determinants affecting income were vary depending on the economic size of the farm, may be rejected. Instead, one can observe that incomes in very small farms are highly dependent on the values statistically significant independent variables, and in very large farms the cash flow is the most important determinant of the income level.

\section{REFERENCES}

1. AAFC, Statistics Canada (2000). Understanding Measurements of Farm Income. Publication 2060/B.

2. Adkins, L.C. (2014). Using Gretl for Principles of Econometrics. 4th ed. Ver. 1.041. Oklahoma State University, Oklahoma.

3. Arbia, G., Piras, G. (2005). Convergence in per-capita GDP across European regions using panel data models extended to spatial autocorrelation effects. L $\square$ Istituto di Studi e Analisi Economica Working Paper, 51, p. 16.

4. Baltagi, B.H. (2005). Econometric Analysis of Panel Data. 3rd ed. John Wiley \& Sons, Chichester.
5. Berbel, J., Rodriguez-Ocaña, A. (1998). An MCDM approach to production analysis: An application to irrigated farms in Southern Spain. European Journal of Operational Research, 107, pp. 108-118.

6. Cary, J.W., Holmes, W.E. (1982). Relationships among farmers' goals and farm adjustment strategies: some empirics of a multidimensional approach. Australian Journal of Agricultural Economics, 26 (2), pp. 114-130 .

7. Commission Regulation (EC) No 1242/2008 of 8 December 2008 establishing a Community typology for agricultural holdings. OJ L 335 of 13.12.2008.

8. Ergün, U., Göksu, A. (2013). Applied Econometrics with Reviews Applications. International Burch University, Sarajevo.

9. European Commission (2017). Communication from the Commission to the European Parliament, the Council, the European Economic and Social Committee and the Committee of the Regions. The Future of Food and Farming. COM(2017) 713 final of 29.11.2017.

10. Eurostat (2016). Agriculture statistics - family farming in the EU. Retrieved from: https://ec.europa.eu/eurostat/statistics-explained/index.php?title=Agriculture statistics_family_farming_in_the_EU\&oldid $=352405$ [Accessed 05.05.2018].

11. Frawley, J.P., Commins, P., Scott, S., Trace, F. (2000). Low Income Farm Households: Incidence, Characteristics, and Policies. Combat Poverty Agency and Oak Tree Press, Dublin.

12. Gasson, R. (1973). Goals and values of farmers. Journal of Agricultural Economics, 24, pp. 521-524.

13. Kufel, T. (2004-2018). Gretl program. Retrieved from: http://www.kufel.torun.pl [Accessed 05.05.2018].

14. Nibbering, J.W., van Rheenen, T. (1998). The Development of a Quantitative Method for Setting Research Priorities: A Critical Assessment. Agricultural Systems, 56 (2), pp. 145-165.

15. Pawłowska-Tyszko, J. (2014). Agricultural Farm Income and competitiveness of the tax and insurance systems. IERiGŻ-PIB, Warszawa.

16. Scoville, O.J. (1947). Measuring the Family Farm. Journal of Farm Economics, 29 (2), pp. 506-519.

17. Severini, S., Tantari, A., Di Tommaso, G. (2016). The instability of farm income. Empirical evidences on aggregation bias and heterogeneity among farm groups. Bio-based and Applied Economics, 5 (1), pp. 63-81.

18. Solano, C., León, H., Pérez, E., Herrero, M. (2001). Characterising objective profiles of Costa Rican dairy farmers. Agricultural Systems, 67, pp. 153-179. 
Proceedings of the 2018 International Scientific Conference 'Economic Sciences for Agribusiness and Rural Economy' No 2, Warsaw, 7-8 June 2018, pp. 21-28

19. Sustainable Food Lab (2017). Enabling smallholder farmers to improve their incomes. Improving Incomes Challenge White Paper, September, p. 2.

20. Wallace, M.T., Moss, J.E. (2002). Farmer DecisionMaking with Conflicting Goals: A Recursive Strategic
Programming Analysis. Journal of Agricultural Economics, 53 (1), pp. 82-100.

21. Wooldridge, J.M. (2013). Introductory Econometrics. A Modern Approach. 5th ed. South-Western Cengage Learning, Mason. 